Article

\title{
Cameroon: Perspectives on Food Security and the Emerging Power Footprint
}

\author{
Adam Sneyd \\ Department of Political Science and the International Development Studies Program, University of \\ Guelph, Guelph, ON N1G 2W1, Canada; E-mail: asneyd@uoguelph.ca; \\ Tel.: +1-519-824-4120 (ext. 53568); Fax: +1-519-822-7703
}

Received: 13 January 2014; in revised form: 17 March 2014 / Accepted: 26 March 2014 /

Published: 9 April 2014

\begin{abstract}
The reality that food security is a contested concept and ultimately a matter of perspective has considerable implications for Cameroon's partnerships with emerging powers. This article argues that Cameroon could achieve a more sustainable and equitable food system if greater policy attention is directed toward understanding the range of perspectives that contend to influence food security policy, and to engaging with viewpoints that vie to assess the 'footprint' of emerging powers in this area. The analysis presented below shows that the principal perspectives that compete to influence Cameroonian policy vary depending on the particular dimension of food security or aspect of emerging power activity under discussion. This finding challenges previous typologies, and encourages more nuanced interpretations of debates on these matters moving forward.
\end{abstract}

Keywords: food security; emerging powers; footprint; perspectives

\section{Introduction}

To paraphrase and put a twist on George W. Bush's infamous aphorism, the idea of food security is a "uniter" and a "divider". Over the past decades, as billions of people and communities around the world have developed more intense and continuous connections across borders, few political leaders, researchers, or media commentators have dared to argue that food security is a peripheral issue. Today, calls for an end to hunger and the realization of sustained food security are ubiquitous. However, expert opinions on the interventions, policies, and practices necessary to secure a self-sustaining, hunger-free future could not be more split. 
This article aims to augment the evolving literature on food security perspectives [1-6]. To do so it identifies divergent perspectives on food security imperatives in Cameroon and presents contrasting views on how emerging powers might be changing the country's food security situation. For the purposes of this presentation, the term emerging powers is used to denote emerging market economies and encapsulate the reality that these economies can project power over many aspects of development in Africa, including food security. Public agencies, banks, and firms controlled by or registered in these economies have executed many new portfolio and direct investments in Cameroon, and are actively developing new trade links. Through honing in on each of finance, foreign direct investment (FDI), and trade, the article presents a comprehensive range of opinion on the food security "footprint" of emerging powers in Cameroon.

The article ultimately presents an analysis of perspectives on food security and on emerging powers that challenges the notion that it is useful to develop universal categories of viewpoints on both of these matters in Cameroon. In stark contrast to the findings of Yengoh et al., it is argued below that efforts to group opinions on food security imperatives in this country together in ways that apply across all dimensions of food security could obscure more than they reveal [7]. While it is possible to group or categorize perspectives that prominently vie to influence policy related to the availability of food, for example, these opinion categories do not capture the principal flashpoints in local debates on other aspects of food security, such as socio-economic accessibility or nutritional and cultural adequacy. The article also finds that perspectives on emerging powers similarly elude universal categorization. The primary views that animate opinion struggles in this area depend upon which aspect of the emerging power food security footprint is under discussion. Taken together, these findings suggest the need for a more nuanced treatment of perspectives on food security and emerging powers.

To conduct this study the author tapped and built upon a contact network he forged during extended country-level research in 2010 [8]. Original work to identify flashpoints in perspectives on this topic was executed in Yaoundé and more remotely in the Centre, Littoral, Northwest, South, Southwest, and West regions over a two-month period in 2012. Through semi-structured interviews, participant observation and informal conversations, the author ascertained the perspectives of elite researchers and officials representing an array of stakeholder groups. Specifically, over two-dozen representatives of civil society organizations working on food, forests and resources were interviewed. Officials at ministries including Agriculture, Economy, Finance, and Forests directly informed this work, as did consultants retained on numerous initiatives associated with these ministries and with the Office of the Prime Minister. Interviews were also conducted at the country offices of the World Bank, the International Monetary Fund, the United Nations Development Programme, the Food and Agriculture Organization (FAO) and at project and programme offices linked to these organizations and to other multilateral and bilateral agencies. Additionally, extended conversations and document collection occurred at offices of international research organizations such as the Centre for International Forestry Research. Several discussions on food were also arranged with trade officers at diplomatic missions representing Cameroon's emerging and traditional trade partners. Finally, private sector investors in agriculture and food of national and foreign origin were also engaged in lengthy exchanges.

Several prominent personalities interviewed for this study offered perspectives that did not differ much from those that they had previously contributed to sources that are readily available in the public domain. Consequently, a few interviewees in this position are identified in the text that follows. 
However, owing to the small size of the community involved in food security research, policy, and practice in Cameroon, the vast majority of quotations recounted in this article have been rendered anonymous. The names, organizations and stakeholder type of interviewees have been redacted from in-text and block citations, and interview locations have also been withheld. This methodological approach aims to protect the safety and security of the individuals that contributed to this study. Food security remains a politically sensitive topic in Cameroon. As emerging powers have the potential to provide considerable flows of additional financial resources to the country over the coming years, the high-level political sensitivity of this topic is palpable. As such, the controversial quotes re-presented below have not been attributed to particular individuals or institutions.

To triangulate perspectives articulated during interviews and informal conversations - the bulk of the material the article draws upon - the author collected and reviewed over two hundred primary documents linked to food security topics while in Cameroon. Most of these materials were collected in big cities and regional centres including Bamenda, Buea, Douala, Ebolowa, Edea, Kribi, Limbe, and Yaoundé, and many remain unavailable online. They include pamphlets, public information, consultancy reports, newspaper articles and other unpublished, unofficial, or internal corporate analyses. Several of these documents are noted in the references. They have variously been employed to provide contextual knowledge, or as examples to bolster particular points. Note that these materials were not subject to a content analysis using data analysis software. The author has conducted that exercise and the results have been reserved for another scholarly publication on food security perspectives in Central Africa more broadly. Here, these works have simply been used to reinforce the interview data. In addition to these primary sources, statistical series obtained from the national statistics office and the IMF country office were accessed and reviewed. However, many statistics that speak to the broader food security situation in Cameroon are not reproduced as these have been comprehensively presented elsewhere, particularly in the UN Special Rapporteur on the Right to Food's report on his 2012 mission to the country [9]. References to statistical material have also been kept to a minimum to focus attention on the topic at hand-perspectives - and to avoid over-reliance on potentially "poor" numbers [10].

The story this article presents confirms that civil society advocates, development practitioners, government officials, and food researchers in Cameroon generally agree with the new conventional wisdom that food security is a multidimensional issue [11,12]. Consequently, the article is attentive to the multiple dimensions of food security that animate the work of the Rome-based UN specialized agencies and the outputs of the UN Special Rapporteur. In particular, it embraces the latter's take on the principal aspects of food security that can contribute to the realization of the right to food or detract from its achievement. The food security definition agreed by official attendees at the 1996 World Food Summit could have served as this article's point of departure. The definition subsequently embraced by the Food and Agriculture Organization (FAO) - that food security is a situation that exists when all people, at all times, have physical, social and economic access to sufficient, safe and nutritious food that meets their dietary needs and food preferences for an active and healthy life-is indeed comprehensive. However, the UN Special Rapporteur's formulation is arguably framed in a way that enables more direct attention to be drawn to the multiple dimensions of food security, and to the politics of food security. While this multidimensional formulation is not uncontroversial, and has not remained constant over time, it has been employed here owing to its clarity. The Rapporteur's focus on 
three dimensions of food security is parsimonious and also congruent with the article's attention to three aspects of emerging power engagement. Specifically, Olivier De Schutter's framework focuses on the physical availability of food; on the social, economic, and physical access to food; and on the nutrition, safety, and cultural appropriateness or adequacy of food $[9,13]$.

This exercise builds upon De Schutter's use of these dimensions. It does so by not employing these dimensions as fixed categories to which universally valid prescriptions to enhance food security can be applied. Rather, in this article, each dimension of De Schutter's approach is used to anchor an analysis of the perspectives that contend to influence policy. The overall rationale for this modified use of availability, accessibility and adequacy is as straightforward as it is argumentative. Simply put, it is argued here that this approach enables more rigorous understandings of the subtleties of political contests over food security than analyses that paint the issue of contending opinion with broader brushstrokes or that gloss the importance of perspective entirely.

Taken together, the diversity of opinion on food security and emerging powers in Cameroon analyzed below has considerable implications for the country's future food security policies. It draws attention to the possibility that food security strategies could be better targeted if policy and decision-makers understand and act upon the reality that opinion contests sound different on each aspect of this phenomenon and also on each aspect of the dynamic interventions of the continent's incipient sources of finance, direct investment, and trade. To make the argument for a more nuanced approach to understanding the perspectives that vie to influence food security policy and assess emerging power interventions, the article first presents perspectives on the availability, accessibility and adequacy of food in Cameroon. Expert opinions on how emerging powers are changing food security through finance, FDI, and trade are then sequentially introduced. The concluding section discusses several implications of this story for food security policy in Cameroon and in Africa more broadly.

\section{Perspectives on Availability}

Food security analysts in Cameroon generally agree that significant improvements to the country's governance context will be required for the availability of food to be sustainably enhanced [14]. There also seems to be nearly universal agreement on the need for Cameroon to take better advantage of its diverse agro-ecologic zones $[15,16]$.

While the availability of food is sufficient at most times of the year in most regions of the country, analysts also agree that the consequences of the availability status quo are stark. The World Food Programme (WFP) and the FAO found in their 2011 Comprehensive Food Security and Vulnerability Analysis that, at any given time, at least 30 percent of Cameroonian households in rural and urban areas remain vulnerable to food insecurity. Over 48 percent of the working population in Cameroon depends on agriculture and on pastoral activities, yet it is estimated that only 20 percent of the country's arable land is currently cultivated [17]. Of over 21 million Cameroonians, at least eight million live in rural areas. The majority of these rural people-over 55 percent-fall below the national poverty line [18]. According to the results of a recent large-scale food security study, nearly 10 percent of households in rural Cameroon are food insecure [19]. These people generally do not produce enough food to feed themselves, and they are typically too poor to be able to purchase (access) adequate food. The WFP/FAO analysis also found that an additional 10 percent of rural households are in a persistent state of relative food insecurity. People suffering from this productivity 
and health-sapping condition are forced to skip meals, to reduce the size of their meals or to buy the cheapest available foods. Food security experts have concluded that without renewed efforts to scale up the domestic availability of food beyond present levels, rural Cameroonians will continue to have deficient access to adequate food. As we will see below, however, the consensus on the need to enhance availability is relatively thin. Domestic opinion on the ways and means to sustainably augment the production of food crops remains starkly divided (see Figure 1).

Figure 1. Perspectives on Availability.

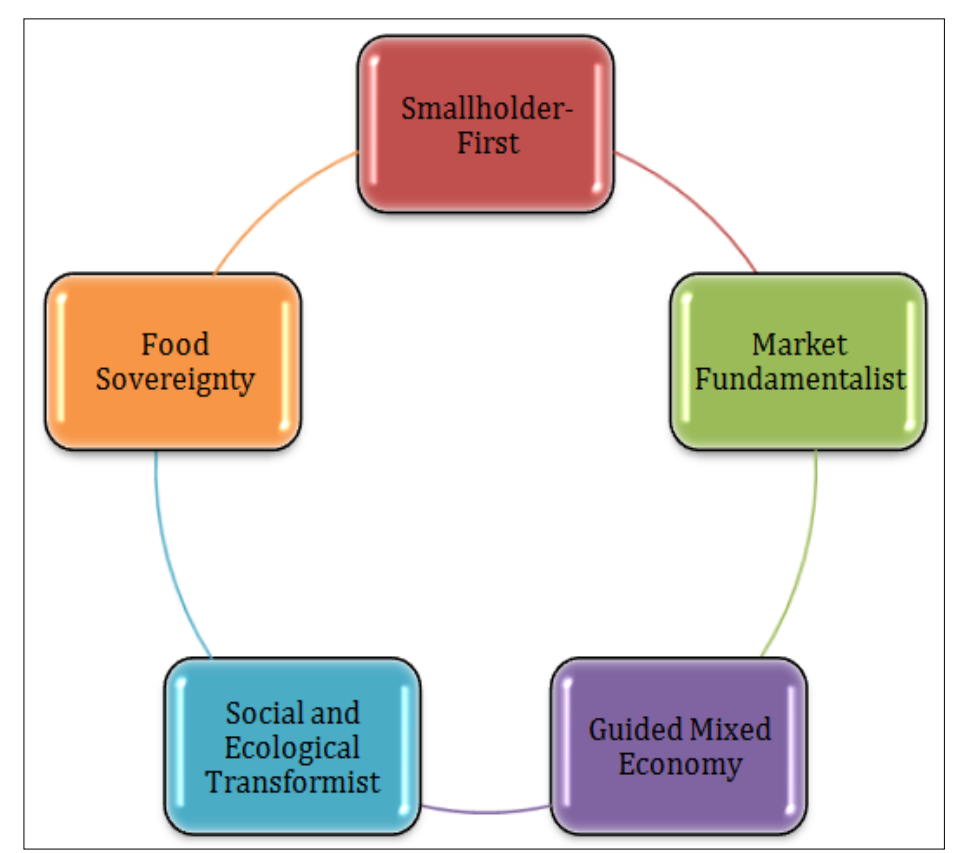

In Yaoundé, several high-level figures continue to advocate conventional technologies and a market fundamentalist perspective on availability that resonate with perspectives articulated by Robert Bates and the World Bank over a generation ago [20,21]. They underscore a need for private sector players to embrace technologies that enable the capture of efficiencies and that reinforce productivity. From this perspective, incentives must be put in place to enable private farmers and agribusinesses to improve the yields of individual crops on an output per hectare basis via the application of synthetic fertilizers, chemical pesticides, and improved seeds. They also must be able to access to the agronomic knowledge necessary to reduce the level of agro-inputs used per unit of output over time. In this light, agriculturalists in Cameroon might eventually reach a point where it pays for them to be attentive to the so-called triple bottom line of people, planet, and profits. Today, however, these thinkers and practitioners consider efficiency and productivity to be "universals". In their prescriptive policy advice they tie the realization of these concepts to the greater uptake of conventional technologies and to the emergence of a new entrepreneurial culture of agricultural risk taking. The pro-market instincts of this group can be encapsulated in their critiques of food activists in civil society.

The mentality of civil society is to go to a job or do what is easy for them. They want something out of that. It is simply rhetoric or talking about things. This is one of my observations. We have lots of seminars and lots of talking. We need more people who are interested in knowing through learning by doing...[we need] more rural risk takers. 
Similarly, others in this camp are often critical of the inefficiencies they associate with the status quo of mixed (non-monoculture) farming across much of the countryside. They generally advocate the introduction of market-oriented single-crop production systems to advance their "universal" imperatives for the sector.

While market fundamentalists supportive of conventional technologies rationalize their approach with reference to generalities and recourse to ideological postures, another group of experts tends to cite the drivers of food insecurity in Cameroon and to offer a more nuanced perspective on the possible ways forward. They note that poor food security outcomes have resulted from deficient capacities at multiple levels, and that the state and the market both have significant roles to play in enhancing availability. From this perspective, an undersupply of entrepreneurial spirit and a lack of conventional inputs have not been the sole drivers of food insecurity. Scarce storage capacities, the under-provision of training opportunities and an exodus to urban areas have been equally consequential factors [16]. In light of these and other impediments such as the poor rural transport network, malfunctioning markets and the countryside's surging dependence on food imports, mixed economy policy entrepreneurs advocate a state-guided approach to enhancing availability (see for complementary perspectives in the global literature [22-25]). As such, they take positive views of the government's 2008 initiative to devote public funds to rapidly and significantly raise the supply of locally produced food crops including rice, banana, and plantain [18].

Proponents of this guided mixed economy approach typically also support the objective articulated in Cameroon's Vision 2035 policy document to "restructure the rural world for more professionalism, with dominance of large and medium-scale undertakings" [26]. From this perspective, the private sector needs to be "crowded in" by public investments and guided by the National Programme for Food Security and the Agricultural and Livestock Sector Programme [27]. Durable enhancements to availability will not simply flow from the creation of new incentives for farmers to independently pursue intensification, irrigation and improved equipment. Public investments in research extension services, in storage and processing to prevent post-harvest crop loss, in improved farmer organization and in rural finance are all deemed to be part and parcel of a robust push for productivity [17]. In sum, these views on professionalizing the sector and encouraging larger scale production are currently the "mainstream" local perspective on the ways and means to improve availability.

Another camp of high-level figures support many of the middle-of-the-road policy objectives listed above, but question the desirability of a push for medium and larger-scale agriculture. These thinkers assert that smallholders should be at the apex of efforts to bolster availability on the grounds that smallholders produce the majority of the country's sustenance and cash crops [9]. They argue that small farmers "produce most of the foods necessary" to realize food security, including maize, millet, sorghum, rice, manioc, potato, yam, plantain, green beans, peanuts, sesame, pineapple, banana, and several other vegetables and fruits [28]. Adherents to this conventional smallholder-first approach have also called for improved seeds, and for the domestication and commercialization of species that could improve the availability of protein through the development of small-scale farming enterprises and marketing systems for indigenous cane rats or Latin American guinea pigs. Echoing the UNDP's Africa Human Development Report 2012 and other high-level civil society sources, they push especially hard for investments in the development of producer groups to enable smallholders to sell in bulk and enhance their farming, financial and managerial capacities [29-31]. While not necessarily 
unsupportive of larger-scale agribusiness, smallholder-first advocates are quick to point out in their writings and in person the possible shortcomings and dangers that might be associated with the view that "bigger is necessarily better".

Others whom are very supportive of smallholder agriculture do not buy into the notion that conventional approaches to intensification and ongoing reliance on the country's cash crop and plantation export models will enhance availability. On social and on ecological grounds, these individuals seek to transform agricultural practices to enhance availability. In so doing they echo a prominent perspective in the global literature (see [32-35]). They note with concern that Cameroon continues to specialize in producing and selling banana, cacao, coffee, cotton, green beans, and rubber to trading partners in the United States, Europe, and China. In contrast to the position that this orientation enables the country to exploit its "great export potential", they highlight the ways that this specialization can undermine the domestic production and availability of staples and macronutrient rich foods $[19,36,37]$.

These figures also challenge the government's supportive stance vis-⿳亠丷⿵冂-vis large-scale operations on social and ecological grounds. On the former, they exhort the government to embrace concrete measures to improve the fundamental rights of plantation workers, and dispute the notion that export-oriented plantations improve the accessibility of food [38]. Critiques of renewed efforts to take land out of food production and introduce the large-scale production of export crops can be quite direct, for instance, in arguing that this practice is totally "stupid".

It is totally stupid to have these types of farms. We have some existing farms growing those things. Let's assess how they work, and what has happened with them, and then decide if we want to continue in that direction. This [assessment] is not happening.

Beyond offering similarly harsh evaluations of the ecological implications of intensive cash crop and plantation models for the long run productivity of soils and the availability of downstream protein-rich foods, such as fish, experts in this critical camp advocate a new model for sustainable agriculture. In particular, they echo the calls of the UN Special Rapporteur on the Right to Food for greater engagement with agroecological approaches and techniques to reduce off-farm inputs, and maximize rainwater harvesting and nitrogen fixation through on-farm innovations [13]. From the perspective of these social and ecological transformists, climate change and variability add extra impetus to the quest for a new model that prioritizes sustainable enhancements to availability.

Related to this critical grouping but also distinct from it is a final cluster of perspectives on availability that directly assert the need to substitute imported foods through a resurgence of domestic production driven by farming communities themselves (for congruent perspectives in the global literature see [39]). This food sovereignty perspective decries the reality that Cameroon spends an ever-greater percentage of its foreign exchange earnings on food imports. For example, in 2009 the country spent seven times more on food imports (at least 550 billion CFA francs or the equivalent at the time of over \$1 billion USD) than it did in 1994 [19]. As this trend has intensified, civil society groups have coalesced around a campaign that aims to familiarize consumers with domestically produced foods and in so doing generate more demand for, and production of, local foods [40,41]. This campaign has documented a veritable surge of chicken, fish, flour, milk, oil, onion, rice, and tomato imports over the past decade. Data from the IMF Resident Representative's office indicate that this 
trend has come at an increasing cost. In 2011 Cameroon spent the equivalent of 18 percent of its foreign exchange earnings on imported cereals, fish and "industrial foods" [42]. Only several years earlier, this figure stood at 13.6 percent [28]. As a consequence, the country has had less hard currency on hand that could be productively employed to develop its agricultural storage and marketing infrastructures, or build the capacity of local agribusinesses.

In this context, supporters of food sovereignty have called for the introduction of food security safeguards domestically and internationally, and for a demand-driven approach to encourage Cameroonians to eat more of what they produce, and to produce more of what they eat. They have also drawn attention to and sought to redress specific import-related disasters, and exposed embezzlement at the Ministry of Agriculture. On the former, in 2004 adherents to this approach drew attention to the consumer risks associated with an influx of imported frozen chicken. This particular surge cut chicken prices at the market, but also caused innumerable health problems owing to the fact that Cameroon did not have a viable cold storage chain [43]. Regarding the latter, devotees have documented practices such as overbilling, fictitious deliveries, "phantom" missions, "ghost" seminars, redundant training, and the "spreading around" of expenses to avoid internal oversight and accountability systems. From a food sovereignty perspective, the persistence of such practices at the Ministry suggests that a new push to augment availability must be organized and managed from the bottom-up by farmers, farming communities and their empathizers.

\section{Perspectives on Accessibility}

Accessibility has been the headline food security issue in Cameroon since riots occurred in markets in Douala and elsewhere at a time of high food price stress in 2008. The government's initial response to price pressure was to suspend tariffs on imports of frozen fish, rice, and wheat flour, and to reduce tariffs on other imported foods [44]. A freeze on fuel prices and a fuel subsidy scheme were also introduced to alleviate the effects of price inflation. This move sought to halt hunger and anger associated with higher cooking fuel prices. Price rises in this area had created a nasty food security trade-off: they had significantly reduced the quantities of food that consumers were able to afford to put in their cooking pots. Additionally, the government subsequently put in place a process to initiate travelling food markets. These roadshows were tasked with selling food at rates targeted to bring down prices in local markets.

Political viewpoints on the appropriate role of the state and analyses of the distributional consequences of these measures have been at the core of two distinct perspectives that have emerged on these government actions. Several market fundamentalists have continued to portray food security as a challenge that is primarily manifested through "inexorable" rises in the prices of "basic necessity" foods [45]. They have depicted the government's interest in the language of food security as being rooted in the food price.

This is a political thing related to social unrest. Food security is a political issue, and it is a price issue. The government does not have the political will or the political capacity to recognize that it [food security] could be a problem bigger than price. 
These experts have generally decried the government's efforts to subsidize fuel, lauded the tariff reductions, and pushed for a stronger and more diverse food trade within and beyond the Economic and Monetary Community of Central Africa (CEMAC).

On the other hand, supporters of a guided mixed economy approach have underscored the skewed distributional consequences of the fuel subsidy and have pushed for the introduction of comprehensive public safety nets to address any accessibility issues that emerge after the subsidy is removed. In this light, the reality that nearly 70 percent of fuel subsidies have accrued to the richest 40 percent of households, and that the poorest 20 percent of households have received less than one percent of the gasoline subsidy and only 13 percent of the kerosene subsidy, are viewed as grounds for a new model [46]. Practitioners that recognize a role for the state in ensuring sustained accessibility improvements have successfully lobbied for the piloting and introduction of a conditional cash transfer programme calibrated to target those most in need [13]. Supporters of smallholder-first approaches, of social and ecological transformation and of food sovereignty have in several cases backed efforts to make the government's accessibility initiatives work better for resource poor and hungry people (Figure 2).

Figure 2. Perspectives on Accessibility: Subsidies and Safety Nets.

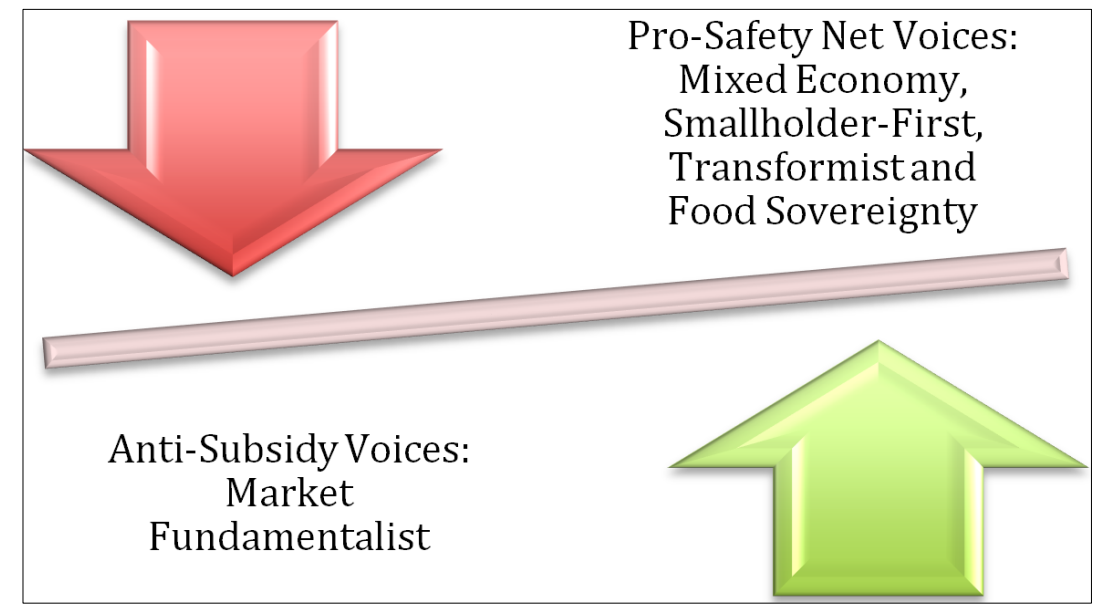

The five-fold categorization of views on availability similarly cannot be applied to perspectives on other government initiatives that aim to enhance accessibility beyond subsidies, their successors or tariff reductions. At present, there are three distinct positions on these measures. For example, there is a laudatory take on government efforts to bankroll and organize traveling caravans or markets that aim to promote lower prices on basic necessities. In this light, MIRAP (la mission de regulation des approvisionnements des produits de grande consummation), the public agency tasked with buying, importing, stocking, and selling to undercut high market prices, can do no harm. Commentators in the official national daily newspaper, for instance, have noted that "buying in bulk" has enabled these traveling markets to offer significantly cheaper chicken, beef, and palm oil [47]. Others have assumed the existence of this government initiative, but have called for reforms that could enable it to both better serve people facing accessibility challenges, and better support the food producing countryside. In particular, they have promoted the extension of these temporary markets to more rural locations, and the inclusion of more local products such as manioc, millet and maize so that local producers can reap gains from future efforts to sell food at regulated prices [9]. 
While laudatory and reformist points of view tend to a guided mixed economy approach, critical takes on MIRAP have been articulated by supporters of bottom-up food sovereignty and also by market fundamentalists (see Figure 3). For these crosscutting critics it "seems simply stupid" to return to a stocking and subsidy system that "unfairly competes" with the private sector. Critics also portray this system as "unsustainable" insofar as it could be "perverted" to enrich those tasked with importing and stocking essential commodities along the same lines that similar systems across Africa were looted during the 1980s (for a related discussion of "bias" in the politics of rice accessibility and subsidies in Cameroon, see [48]).

Figure 3. Perspectives on Accessibility: MIRAP.

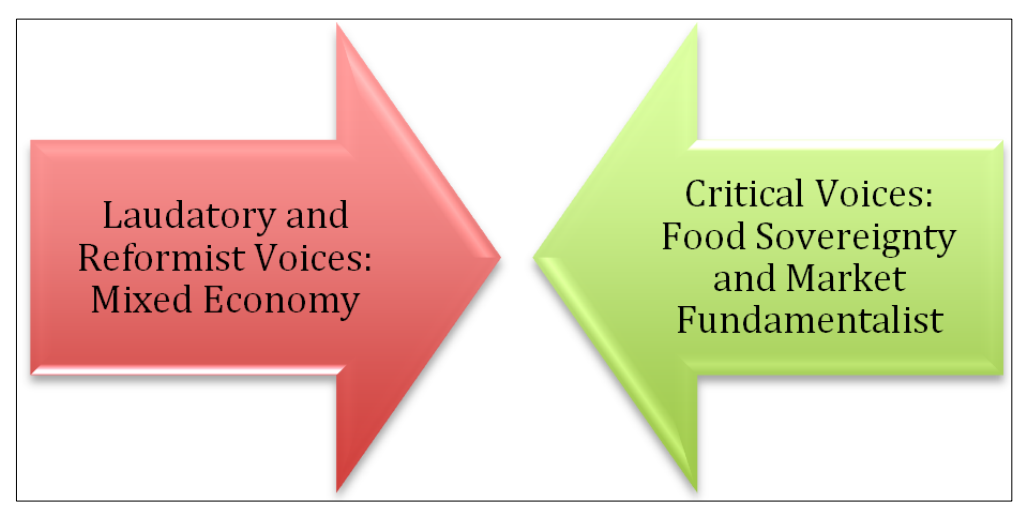

While many experts who hold divergent standpoints on availability are convinced that government actions to reduce food price inflation at a time of growing import dependence are necessary, they have also drawn attention to additional accessibility challenges. For instance, guided mixed economy advocates and supporters of food sovereignty alike have argued that supply-side distortions such as hold-ups and price fixing in the domestic beef trade are often a significant driver of price inflation in regional and central markets. Similarly, as I have detailed elsewhere, the cross-border trade in Cameroonian banana, manioc, and plantains engaged in by Gabonese and other "buyam-sellam" traders is seen by many to be an additional source of price pressure on traditional staples [49]. Maize hoarding by breweries in anticipation of the annual seasonal availability "low" has also been highlighted as a possible factor driving food prices higher each year. Hold-ups, price-fixing, shadowy exports, and invidious strategies to mitigate seasonal availability challenges are amongst the factors that have stimulated renewed calls for higher wages, social protection, and a stimulus package/incentive structure for the renewal of domestic food production [9,38]. These and other prescriptions for accessibility have emanated from sources that fall across the spectrum of opinion on availability.

In addition to the persistent accessibility challenges listed above, domestic food security experts have generally emphasized that there is a need for greater attention to improving the country's rural roads, to reducing the transaction costs associated with transporting food and to stimulating new investments in food preservation. Each of these constraints makes a significant contribution to Cameroon's exorbitant rates of food wastage. While estimates very, it is possible that 25 percent of the country's root and tuber harvests and 50 percent of its fruit and vegetable harvests go to waste each year. Transaction costs, for example, constitute a significant barrier to entry into the food transport trade, and also to the viability and reach of this business. Transporters attempting to move roots and 
tubers from under-served or remote surplus areas to deficit areas in far flung regional centres must allocate significant resources to their budgets for police "fees". At present, where and when roads are poor and the police are on patrol, transporters have incentives to make suboptimal contributions to accessibility. In this context, domestic food security specialists have called for reduced internal barriers to the food trade, and for improved rural storage systems, investments in processing facilities for perishable fruits and vegetables, and for the establishment of a durable cool refrigeration chain. They have also stressed the dangers associated with a status quo where it can be difficult for smallholder cash croppers and families living proximate to plantations to command the purchasing power necessary to access food [50]. Supporters of food sovereignty have elaborated a knock-on effect of such hazards: the high rate of rural out-migration.

Young guys in the village see how their fathers used to be cocoa producers. They see how their fathers became very poor, not because they were not working, but because some things happened that were totally out of the control of the farmers, such as the devaluation of the CFA franc in 1994 and the punishing input cost inflation that followed. Afterwards families ate everything that they had on their farms, and they didn't have enough money to buy food at the market, or to send their kids to school or to pay for health. Young guys didn't want to have that life. They went to the cities, and they became rice eaters, increasing the demand for imported rice...At the end of the day there was nobody back on the farm, and all these young guys were employed doing unofficial small jobs. They now eat the cheapest possible meal available in the city: imported rice with a little tomato and Chinese mackerel.

Accessibility challenges near big plantations have also led in some instances to disturbingly violent outcomes. Near one long-standing oil palm concession in 2012 someone was killed.

Killed for "stealing" palm nuts. I saw the brother who also got a bullet, and the family told me that the boys weren't stealing palm nuts to sell. They went into the plantation to fish some of the small rivers in the area. The company has hired people to protect their nuts, but these boys were fishing. For me it means that they were hungry. They knew the risk of accessing food in this way, but they felt they had to do it.

Deficient purchasing power underpinned this sad tale, and food security authorities nearly universally recognize that enhancements to rural and urban incomes are necessary for a more food-secure Cameroon.

\section{Perspectives on Adequacy}

The disturbing reality of inadequacy in the diets of many Cameroonians is evident in the fact that at least one in three children suffers from chronic malnutrition [9,13]. Protein deficiencies are also common amongst all age groups. That being said, many social and ecological transformists consider the traditional domestically cultivated, gathered and hunted foods that Cameroonians typically prefer to be one of the populace's key sources of essential micronutrients. Local plates containing wild foods, such as eru, ndole, and mbongo chobi have become "national dishes". In 2012, when researchers asked over 350 market women and food buyers in Buea and in Yaoundé to name their favourite plates 
regardless of cost, the nearly universal response was to mention an identifiable national dish or a local delicacy containing foods "from the forest" [51]. However, households that would typically prefer to eat these foods on a regular basis are now finding it more difficult to consistently purchase ingredients for these plates. As the volume of staple food imports has increased over the past years and staple food subsidies have remained in place, staples have become relatively cheaper. Prices of nutritious forest foods - the traditional accompaniments - have not followed suit. The supply of these foods has been inelastic, and agroforestry innovations have yet to make a durable contribution to sustainably enhancing their availability. Consequently, forest foods have become relatively more expensive. In the context of stagnant incomes, consumers increasingly treat these foods as special occasion delicacies by default, not by desire. As a result, the nutritional adequacy of the average Cameroonian household's food consumption basket is tenuous. Food sovereigntists and agricultural transformists alike have challenged the cultural appropriateness of this dietary transition.

Experts whose prescriptions fall into both of those categories have also challenged the adequacy of the new and often imported foods that Cameroonians increasingly rely upon to supply their daily calories. These thinkers assert that in addition to the gamut of availability and accessibility challenges detailed above, time and economic pressures associated with the informalization of the economy have solidified the status of rice as a default staple. According to luminaries in these camps, food security was not as much of a problem in the past.

We had food security here. We were self-sufficient. When I was a child...only a few times a year we would eat rice. We used to consider rice as being a meal for very, very rich people. One of the things [that] we would say... [is that] all the rich would eat rice every day. Now everything has shifted. If you are very poor you eat rice every day. The cheapest market or restaurant meal that you can purchase is a rice dish. It has flipped.

Survey data produced by the Citizens Association in Defense of Collective Interests, a civil society organization working on food sovereignty, indicate that poor families consume rice four to five times per week, and that average Cameroonians generally consume rice because it is cheap and cooks faster [52]. People consequently feel "unhappy" when they cannot access rice not because they necessarily want to eat it, but because it is a "lifeline". Rather than viewing rice as a "helping hand" in an otherwise suboptimal context, advocates of transformist and sovereignty perspectives have noted that rice might in some cases be a health threat.

In terms of the quality of the rice, we do not as yet have any viable norms or standards. It is possible that we are importing very old rice that might not be suitable for consumption, as happened recently in Burkina Faso. You cannot sell deteriorating rice stocks to places with high food safety standards. You can sell them in the places where you are least likely to be arrested. Here if it looks like rice they will put it on the market.

Market fundamentalists have countered that there is nothing necessarily wrong with imports that now provide food for the masses, and that the "clock cannot be rolled back" on economic globalization. For their part, adherents to guided mixed economy points of view have pointed to the government's recent efforts to establish a food safety agency and 70 new norms for agrifood health and safety [44]. Along with believers in smallholder-first agriculture, these practitioners have generally 
viewed the government's recent efforts to renew the local production of rice in a positive light (see Figure 4). These measures have included the articulation of a national rice strategy, and the implementation of donor-supported rice projects (and multi-crop projects involving rice) that aim to: enhance the production and distribution of improved rice seeds; scale-up tractor-based rice cultivation; augment processing capacity; and generally improve the competitiveness of the sector [15,53]. Food sovereignty enthusiasts agree with the overarching objective of a push to substitute rice imports, but seek a more genuinely bottom-up resurgence of the sector. They, along with transformists, remain unconvinced that the present push to address the country's "rice deficit" will alleviate the factors working against "dietary diversity" in Cameroon. For them, rice is seen as a symptom of food insecurity, and only one possible component of a quest to "cure" the nutritional deficiencies presently associated with the dietary homogeneousness induced by "cheap" and "easy" rice.

Figure 4. Perspectives on Adequacy: Rice.

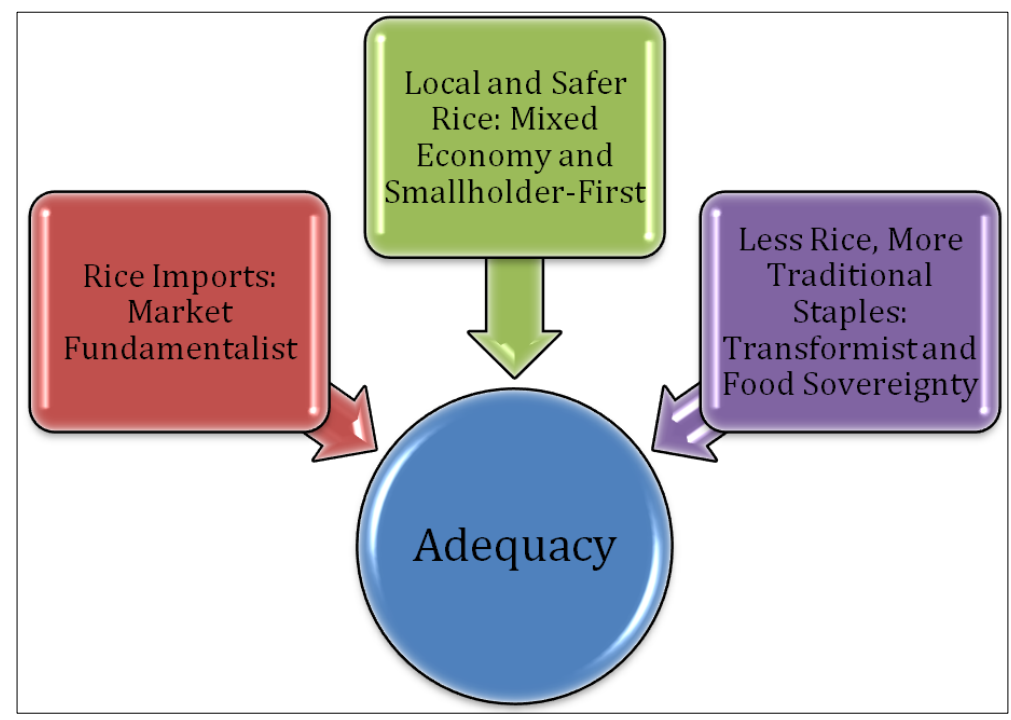

\section{Emerging Powers and Finance}

Emerging powers are having considerable impacts on the availability of food in Cameroon through their efforts to scale up development assistance flows targeting agricultural challenges; through the greater provision of state-backed loans for farming technologies; and through their participation in large-scale infrastructure projects. In each of these areas the engagements of particular powers tend to be attention or headline grabbing. Regarding agriculture-specific development assistance, disbursements from these powers have typically been rooted in the old project model, and have been pursued on both multilateral and bilateral bases.

While it can be difficult to ascertain the perspectives of many domestic food security experts on the country's new development "partners", the notion that South Korea is a rising source of consequential and effective development assistance is broadly shared. Unlike Cameroon's other rising sources of finance, South Korea has allied its aid work with the OECD Development Assistance Committee's aid effectiveness agenda. As a result, some experts have concluded that Korea's interventions exude a different orientation than those of other powers detailed below that have yet to implement aid effectiveness principles such as alignment with national development and poverty reduction objectives. 
This perspective on Korea's interventions is consistent with the findings of Sato et al. on the diversity of approaches and values projected by emerging powers in the Cambodian context [54]. In this light, Korean assistance has targeted food security and availability priorities in ways that other emerging powers have not. In particular, Korea has launched a pilot project for irrigated and mechanized rice that resonates with the language of the national rice strategy [55]. While transformists have challenged the conventional technologies built into this one-off project, adherents to the guided mixed economy approach have generally been supportive. From their perspective, the project will contribute to the availability of local rice, and is also notable for its similarity to the modalities that Cameroon's "traditional" bilateral partners adhere to in the era of aid effectiveness. For example, Japanese Cooperation has rolled out a project that targets other core aspects of the national rice strategy: improved rice seeds and extension services. In view of these parallels, food security practitioners do not generally consider South Korea to be an outlier amongst Cameroon's traditional sources of public assistance for agriculture. Rather, Korea's direct approach to addressing an availability challenge (whatever the possible environmental shortcomings) is generally seen to be remarkable for the ways that it stands out from Indian and Chinese development finance strategies.

On the former, Indian public financial support for agriculture in Cameroon has differed from the Korean model insofar as it has resuscitated tied aid. This strategy has been met with a gamut of stinging local criticisms. In 2009, the government of Cameroon approached Exim Bank of India for a loan and subsequently received a $\$ 37.65$ million USD credit to import equipment to scale-up the farming of rice and maize [49]. The disbursement of this loan was tied to the purchase of made-in-India tractors that were unveiled to the public at an agricultural fair held the following year at Ebolowa, the capital of the country's South Region. While these tractors were procured on credit ostensibly to enhance food availability, food watchers across the opinion spectrum have been quick to point out that to date none of the tractors have been utilized. As a protracted battle has emerged over their allocation to agricultural schools, public projects, private operations, and seed farms, the tractors themselves have become "planted to the ground" at the site of the agricultural fair. According to several sources the "battle" over allocation has also involved the efforts of a group of government insiders or their agents to unofficially sell these tractors to individuals in the private sector. As one businessman recalled, "five or six different people have tried to make deals with me for the same tractors". Market fundamentalists, smallholder proponents and food sovereignty supporters alike have decried this politicized "waste of time, energy and money". Others holding guided market and transformist views on availability challenges have characterized "tractor-gate" as a boondoggle involving inappropriate technologies for which there was little demand and even less absorptive capacity.

If India's public approach to agricultural finance for availability can be characterized as big ticket tied aid, many food security professionals have asserted that a Chinese strategy is "missing in action". While domestic subsidiaries of Chinese firms engage directly in agricultural production, public financiers, such as China EXIM Bank and China Development Bank (CDB) have not directly supported investments aiming to bolster the availability of food. Instead, EXIM has primarily disbursed loans to the government of Cameroon for large infrastructure projects, including the construction of hydroelectric dams, the development of a deep-water port at Kribi and improvements to the Douala-Yaoundé highway. Chinese companies seeking to acquire firms operating in Cameroon's resource sector have attempted to tap these public banks, but as yet, their focus continues to be on 
banking marquee one-off projects [56]. As the government has taken on extensive new debt obligations, guided mixed economy voices have expressed concerns that these projects might be "crowding out" public investments in agriculture and in the improvement of rural roads. From a more market fundamentalist orientation, some have claimed that an artificial debt-fuelled rush to build has sidelined efforts to analyze the possible spillovers from these projects on food availability and employment [18]. Many have lamented the fact that food security safeguards were not built into these projects, and charge that they will deflect future investments from agriculture. These critical voices note that the government will have a vested interest in prioritizing action on unforeseen bottlenecks that emerge upstream (deficient resource transport corridors) or downstream (poor distribution networks) from these projects over other unrelated development and food challenges in the future.

The most prominent expert perspectives on the food security impacts of the over 500 billion CFA francs (€758 million) China earmarked for infrastructure investments in Cameroon in 2011 and of subsequent Chinese loans have honed in on the issue of accessibility. The President's view on the matter, articulated in the government's international public relations campaign, is that "the list of things your country [China] has done for us...is unanimously appreciated by my countrymen" [57]. In 2012, as the President was preparing to attend the ceremonial launch of construction on an EXIM-backed dam project, however, the professed "unanimity" broke down in a very public way when workers on the dam downed tools. According to one food expert, labourers earned 45,000 CFA francs (roughly $€ 68$ ) per month, but the employer deducted 36,000 CFA ostensibly for "food costs". Three cabinet ministers were scrambled to put an end to the unrest. Food security analysts from across the spectrum latter lamented that these efforts only aimed to enhance the access that the largely migrant workforce had to cheaper food. They did not seek to address the spillover from high-level action to put more CFA into the pockets of these workers: local price inflation. As civil society groups have raised new questions about the costing of Chinese projects another more thoroughgoing accessibility critique has come to light. If, as some argue, the government has massively overpaid for these projects, then future governments might not be able to pursue deficit financing on innovations required to make food more accessible to more Cameroonians more of the time. Another possible danger highlighted by market fundamentalists and those that seek bottom-up transformation is bad governance. As the UN Economic Commission for Africa has reiterated, debt-fueled projects with inflated costs in the context of poor governance invite the leakage of "phantom" expenses to foreign bank accounts [58].

Considering the diverse financial interventions of emerging powers such as China, India and South Korea as a whole, domestic food security researchers and practitioners are well aware of the differential impacts that current practices could have on the availability, accessibility and adequacy of food. Through the provision of project finance, only Korea stands out at present as contributing to enhancing the adequacy of Cameroonian diets (though transformists contest this analysis). India has used the power of the purse to finance "mutual interest" loans that could ultimately enhance domestic availability if local partners follow through on their responsibilities. China, for its part, has engaged more indirectly in agricultural finance. While local perspectives on the implications of the scaled up provision of finance are mixed and difficult to categorize across all dimensions of food security, there is clear agreement across the spectrum of opinion that the engagements of new financiers are distinct from each other and are highly consequential. 


\section{Emerging Powers and Foreign Direct Investment}

In Cameroon, as elsewhere, foreign direct investment (FDI) in agriculture can contribute to the local availability, accessibility and adequacy of foods. Beyond enhancing food production and creating local cash incomes, FDI can generate new linkages with other activities backwards or forwards from production such as seed production and food preservation [59]. In the context of Cameroon, however, FDI in the sector has been scarce until very recently. An investment charter was signed into law in 2002 after numerous privatizations opened up the sector to foreign ownership, but the national investment promotion agency was not put in place until eight years later [60]. Today it is now possible to argue that foreign interest in agricultural production in Cameroon is considered by activists in civil society to be one of the country's top development issues. Over the past years the FAO has penned a guide for investors, and civil society figures have written numerous reports related to the subject [61-64]. Civil society activism on the possible environmental implications of new land acquisitions for oil palm in particular has captured the attention of wire services, such as Reuters, and of documentary filmmakers [65]. While the extent of new foreign interest should not be overplayed-FDI flows to Cameroon are not outpacing flows to its CEMAC partners - the reality underscored by food security experts is that new investments can have considerable consequences for a rural population that largely lacks formal or registered land rights and is already prone to food insecurity.

Local perspectives on the general food security contributions that FDI can make tend to fall into one of three camps. The more market fundamentalist of these views asserts that moves to incentivize the opening up of sizeable pieces of land for large-scale production can increase productivity and, depending on the crop, enhance availability while bolstering accessibility [66]. Efforts to capture the interest of prospective investors including Biopalm Energy of Singapore, US-based Herakles, and Malaysia's Sime Darby amongst others are viewed in this light to be the most viable way for Cameroon to increase its capital stock in agriculture [55]. FDI, from this perspective, will reduce the relative weight of investments from "sclerotic" and ineffective state-based institutions in the sector over time. It is also considered to be the sole viable route toward social and environmental development.

For their part, guided mixed economy views acknowledge the possible efficiencies, knock-on effects and spillovers from FDI, but challenge approaches that leave progress on food security solely in the hands of investors. Practitioners in this group within and beyond the government recognize that the intensification of existing plantations or efforts to extensively expand areas under cultivation are each associated with significant food security risks [67]. An enabling environment for FDI must therefore be accompanied by government efforts to monitor, evaluate and resolve availability and accessibility challenges that emerge from intensive or extensive FDI, such as employment loss and land-use conflicts [68]. From this perspective, the UN Special Rapporteur on the right to food has also called for the government to reconsider the ultra low land lease rates and taxation levels currently offered to new investors [69]. Here, slightly higher fees and taxes are not viewed to be disincentives to new investments from well-endowed transnational firms. Rather, they are seen to be a key component of resourcing government efforts to address future externalities from these projects.

A coalition of civil society groups that has emerged on the topic radiates a third perspective on FDI that is imbued with transformist, environmentalist and food sovereigntist views. On the former, coalition members have noted that none of the larger prospective investors have committed to 
embracing alternative agricultural technologies. Investors' plans are also considered to be "old fashioned" insofar as they have not articulated strategies to sustainably enhance productivity or efficiency over the long run. That being said, food security considerations have not been the only concerns at the core of the coalition's push for a moratorium on large agricultural concessions [70]. In particular, an environmental critique has been at the forefront of the coalition's most prominent activist focus. The legal and public relations campaigns of its members against the 60,000 hectare oil palm concession granted to SG Sustainable Oils Cameroon (SGSOC), the local subsidiary of US-based Herakles Farms in 2009, have underscored the ecosystem threats associated with this project. Signatories to a grievance on SGSOC that was filed with the Roundtable on Sustainable Palm Oil (RSPO) before SGSOC withdrew from the RSPO in 2012 were also primarily environmentalist in orientation [71]. Even so, the coalition has continued to articulate food sovereignty perspectives. In their comprehensive report on the Herakles project, for example, Samuel Nguiffo and Brendan Schwartz identify a need for food sovereignty alternatives to be prioritized over large-scale concessions [63]. Members of the coalition have also asserted that a requirement for bakers to use a small percentage of flour derived from local tubers or corn could generate more rural employment and consume far less forested land than the SGSOC project alone. Overall, food sovereignty has been at the heart of calls for a moratorium on new concessions until customary land rights are respected, and consultation processes and feedback mechanisms are established.

Attention to these perspectives on FDI and to the ways that they dominate or blur in discussions on specific investments can help to enhance our understanding of the prospects for emerging powers to contribute to food security in Cameroon. It does so through drawing attention to the reality that "diversity" amongst emerging powers is not only evident in their strategies or value orientations relative to each other [54]. Rather, as local food security experts see it, specific emerging powers are presently engaged in projects rooted in dissimilar approaches that command divergent potentials to enhance availability, accessibility and adequacy. While it is uncontroversial to note that the food security impact of FDI will not look the same on projects that target different crops at different scales, there is a tendency in the global literature to paint land "acquirers" or "grabbers" controlled by or listed in the same power with the same brush [72,73]. As such, this section briefly details local perspectives on two direct investments in farming where the same emerging power-China-is involved. Although China is not directly engaged in the provision of finance for agriculture in Cameroon, the local subsidiaries of a Chinese state-owned firm and of a foreign investor now subject to majority control by a Chinese group are independently pursuing actions seen to have contrasting food security footprints.

Regarding the former, the Cameroonian subsidiary of Shaanxi State Farms, IKO, launched a rice project in 2006. That year IKO signed an MOU with the government and leased 10,000 hectares of land on the former site of a defunct Taiwanese rice operation. Initially focusing on cassava and maize in addition to rice, as the project was slowly rolled out it generated sixty jobs for Chinese nationals and employed one hundred locals [74]. According to advocates for a guided mixed economy, the project initially enhanced the seasonal local availability of rice. These specialists also argued that IKO would have a positive long run impact on availability due its efforts to construct buildings aimed to house an agricultural school. Even so, experts in this grouping have asserted that the project is in need of greater oversight on the grounds that such attention could bolster accessibility and adequacy [56]. As questions continue to be raised about the lack of compensation local people received for the loss of 
their customary lands and about deficient environmental assessments, food sovereignty concerns have also been expressed. In particular, many have asserted that IKO is not transparent, and speculation is rampant that some of the food being produced on this project is being exported. If these claims were to be independently verified then doubt would be cast on the previously dominant idea that IKO is durably bolstering availability. According to transformist and food sovereignty stalwarts, research suggests that "organized smallholders using alternative technologies" have a greater potential to sustainably enhance availability and to create more local jobs than IKO.

Owing to its recent launch, the other Chinese-backed project has been similarly non-transparent. In 2008, Sinochem International, a company listed on the Shanghai stock exchange and subordinated to Sinochem Group, acquired a 51 percent shareholding in Singapore-listed GMG Global, a plantation group specializing in natural rubber. Two years later a GMG subsidiary in which local businessmen controlled a 20 percent stake-Sud-Cameroun Hevea-was granted a provisional concession by presidential decree. Initially it was thought that Hevea Sud would develop a smallholder model for a greenfield rubber operation located in Meyomessala commune for the benefit of the people of the President's home village of Mvoméka'a. Since GMG deemed the costs of establishing a new on-site processing facility to enable the small-scale model to be too high, the firm ultimately requested and rolled out an industrial-scale operation near the border of the Dja Wildlife Reserve. In 2012 a 40-hectare nursery was established in the commune, and an initial 800 hectares of land for the plantation were extensively cleared (Figure 5).

Figure 5. Intercropping of Rubber and Rice.

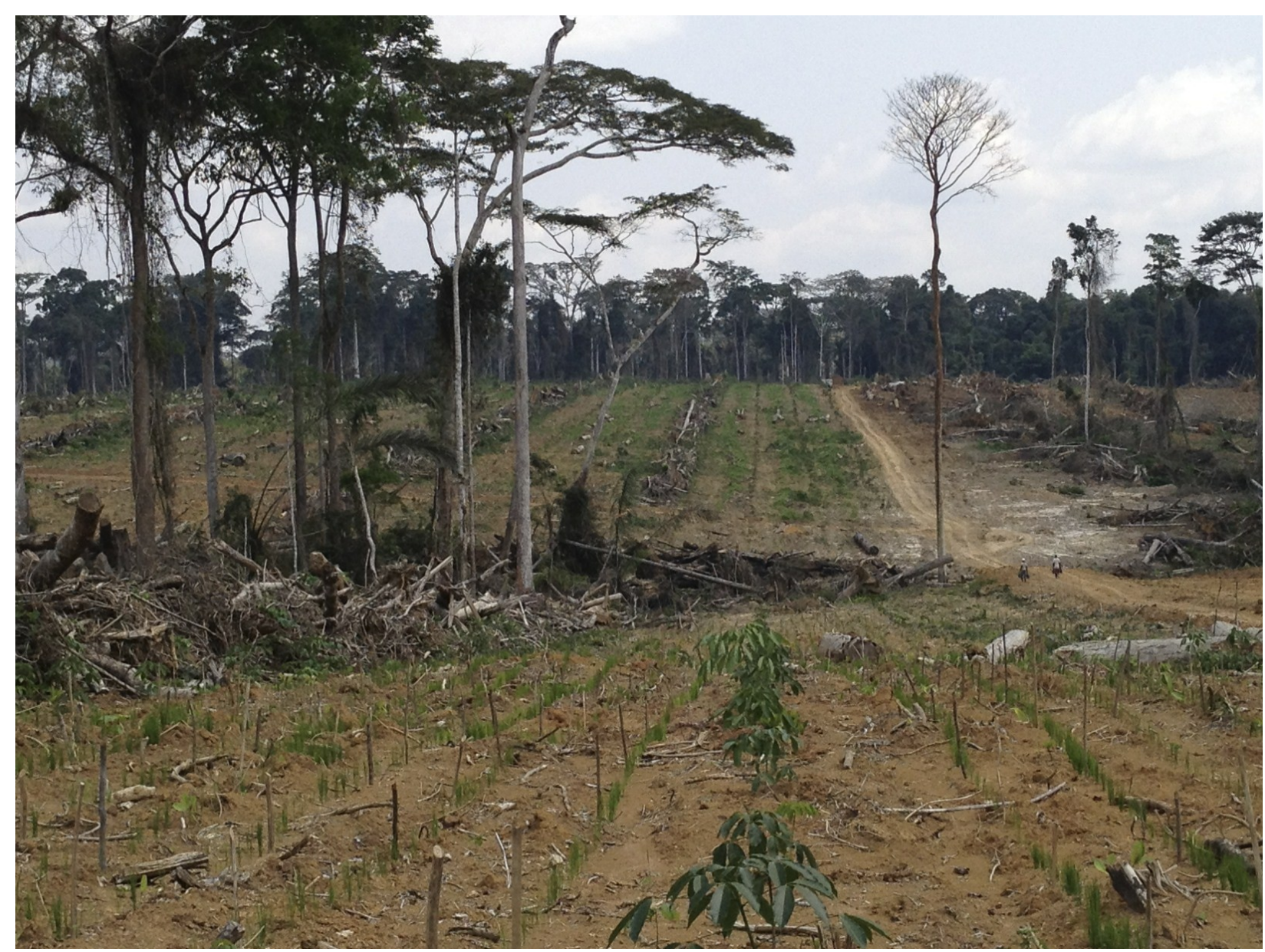


As researchers have not yet shed any light on this project, word of mouth perspectives are the sole source of information on its potential food security implications. Contending viewpoints have been highly charged on Hevea Sud, and have differed considerably from the dominant narratives on IKO. First, there are those who believe that the implementation of a plantation economy in this village will reduce traditional forest-based opportunities to generate incomes, such as the gathering of wild foods, and ultimately undermine the cultural and nutritional adequacy of local diets. These critics have asserted that the project is being constructed on forest concessions that were illegally logged by "very well-known and connected" individuals. They have also claimed that the spectre of local food price inflation will haunt Hevea Sud as the same well-connected personalities will ultimately control the district's new food economy in the absence of food security safeguards.

In sharp contrast, several market fundamentalists view this project to be a real opportunity to showcase how farm-based FDI can enhance accessibility and diets. According to one source, project-related efforts to stimulate more active approaches to food cultivation and transition local diets are accessibility "wins". Others have argued that the company seems to be genuine in its stated desire to enable the people of the concession to learn new skills. They claim that Hevea Sud is committed to doing more than other new investors to ensure social and environmental "balance". While its approach might be paternalistic, as this story goes, the company is ahead of the domestic corporate "responsibility" curve. Amongst other deeds, Hevea Sud has established a buffer with the Dja Reserve that is wider than the minimum legal requirement. It has also engaged in costly learning by doing to arrive at resilient solutions to the food accessibility challenges facing its workers and their community. In particular, of its own accord, Hevea Sud claims to be seeking a lasting remedy to the local protein deficit that its efforts to clear forested land have compounded. The company's director has also made a commitment to developing the capacity of smallholders adjacent to the plantation to produce rubber on a small-scale that Hevea Sud would ultimately purchase. This latter objective could bolster accessibility over the long term, and contrasts sharply with the demise of a similar approach on a long-standing oil palm operation (Socapalm) after it was privatized and fell under the control of the Bolloré Group of France.

From the above discussion it is clear that there are no easy answers. The possible food security impacts of just two new investments linked to one emerging power look wildly different depending upon the perspective of the analyst.

\section{Emerging Powers and International Trade}

Cameroon's European trade partners have seen their respective shares of the country's import and export baskets decline significantly over the past decade. Imports from France, for example, formerly constituted 25 percent of the value of Cameroon's inward trade. Today, less than one-sixth of the country's imports are of French origin. Year on year, emerging power cereal and agricultural input and implement exports continue to displace European origin goods. A similar trend is evident in Cameroon's agricultural exports. These are now increasingly directed towards China and to other "growth" markets in Asia [66]. Domestic food security analysts tend to avoid making general claims about the net impact of these overall trends on availability, accessibility and adequacy. Rather, they make specific claims about technology and food imports, and about food product exports. 
Regarding the country's new sources of inputs and implements, many food security experts believe that emerging powers are having a positive impact on availability through their scaled up efforts to supply tractors and other large-scale agricultural implements to the country. Data the author requested from the National Statistics Institute indicates that excluding imports related to the tractor fiasco recounted above, imports of Brazilian, Chinese, and Indian tractors have been on the rise since 2007. Through selling smaller models at cheaper prices than their French or German competition, emerging powers have increased overall tractor sales. While no data is presently available on the use of these tractors, many food security professionals assume that most are being employed to enhance food production. Less expert agreement is evident on the implications of China's new status as the leading source for smaller (hand-held) agricultural implements for future food availability, and more broadly, for Cameroon's economic transformation or industrialization. While French goods dominated the market for picks and hoes until 2006, today it is difficult to find anything but Chinese goods on offer in local shops in these product categories. Some market-oriented experts have praised Chinese manufactures for enhancing the accessibility of farming tools. Others, taking a more long-term perspective, have questioned the country's reliance on imports of "simple manufactures" that could be "produced locally with locally-available materials". Expert voices across the spectrum from guided mixed economy through food sovereignty views encourage the further development of backward linkages from agriculture to new implement industries that could serve Cameroon's smallholders, and decry escalating reliance on the emerging powers in this area [56].

As regards agricultural inputs, Cameroon's import data are skewed by the reality that it is a significant point of entry for fertilizer, pesticides, and seeds destined for other CEMAC countries. The government's statistics nonetheless capture the growing domestic prominence of synthetic fertilizers of Russian and Chinese origin, and also South Africa's new status as Cameroon's primary source for maize seeds. The data additionally indicate that China is emerging as the leading supplier of a range of chemical pesticides. Interestingly, perspectives on how intensifying dependence on conventional inputs from the emerging powers could contribute to food security in Cameroon mirror the domestic viewpoints differentiated above on availability. Supporters of markets and conventional technologies typically laud the new input market competition. Guided mixed economy voices express concern over the links between movements in the oil price and in the prices of inputs peddled by China and Russia. These experts argue for the renewal or creation of input credit or subsidy schemes, while smallholder proponents push for these reforms to target small-scale producers directly. Transformists reject new trends in the input market and push instead for resources to be devoted to the development of sustainable local systems that reduce and ultimately eliminate reliance on off-farm inputs. Food sovereigntists articulate vociferous criticism of Cameroon's mounting dependence on emerging power inputs, and encourage farming communities themselves to take greater control of farming materials. Contributors to this latter grouping have also drawn attention to the possibility that the volume of products sold as pesticides and fertilizer in Cameroon that are "fake" or "fraudulent" is higher in the recent period than it was before the rising powers captured a greater share of the market. Nonetheless, views on food imports and exports and the emerging powers do not fall along these lines.

On food imports, in the lead up to the global food crisis Cameroon's import bill increased by 11.7 percent per annum between 2005 and 2008 [17,42]. Over the ensuing years costs of the country's principal food imports — including wheat, milled rice, food preparations, malt, and whole dried milk — have 
continued to rise and to be subject to considerable price volatility. From the national statistics it is clear that over 18 percent of Cameroon's available foreign exchange is presently allocated to cover food import costs. In this context, the value of the country's imports of Asian foods has reached an all time high. For example, the value of Thai and Vietnamese rice imports recently equaled the value of Cameroon's wheat imports from France. Beyond cereals, Asian exporters have also become a bigger source of the country's frozen fish and industrial food imports. Surveying this scene, domestic food security experts from across the spectrum of opinion have noted that Asian exporters increasingly exercise power over the access Cameroonians have to basic staples. Some from a more market fundamentalist point of view have challenged the power that emerging market food exporters have wielded over Cameroonian diets over the past five years. In particular, they have underscored the point that China and Russia have generated accessibility challenges in Cameroon through their efforts to restrict rice and wheat exports (see for a contrasting view [75]). In most other cases, critical views on the emerging powers have been less direct. These have been expressed as part of broader critiques of the country's rising import dependence, or within particular calls for new measures to augment accessibility.

Cameroon's basket of agrifood export commodities - including cocoa beans, banana, natural dry rubber, cotton lint, and green coffee - is notable for its relative diversity. That being said, its economy remains susceptible to Dutch disease at times of high commodity prices, and its capacity for value addition is underdeveloped [17,76,77]. As particular emerging powers have acquired a taste for Cameroon's produce they have come to play increasing roles locking the country into its current composition of exports. India and Russia, for example, began to import significant volumes of Cameroon's average grade of green robusta coffee in 2008 and 2009, respectively. For their part, German, Israeli, and Japanese importers paid top dollar for the country's highest quality green Arabica beans during those years. According to the national statistics, emerging powers are increasingly active at the lower end of the markets for each of Cameroon's principal agrifood export commodities. This reality has considerable implications for the future development of processing facilities as the new drivers of demand are treating the place primarily as a down market supplier of bulk commodities. Domestic experts have been relatively silent on the implications of this trend for food security. Most beyond the market fundamentalist camp continue to push for the government and for farmers themselves to pursue opportunities that will enable Cameroonians to add more value to their crops [78]. In the case of cotton, Cameroon's principal export to China, some have dismissed this cash crop on the grounds that it competes with alternatives such as millet and sorghum that directly augment availability. Beyond availability, whether or not the country's new status as a lower-tier supplier for the emerging powers will foster underdevelopment or enable the populace to access adequate food is a trade-related food security concern that domestic food security analysts will need to further engage with moving forward.

\section{Conclusions: Perspectives and Policy Space}

The finding that perspectives on food security challenges and priorities sound different depending upon which dimensions are under discussion helps to clarify the political complexity of the space where policies are developed. Attempts to simply employ Olivier De Schutter's dimensions of food security as categories to which universal prescriptions for reform can be applied gloss the political complexity recounted above [11]. In this analysis, the three dimensions of food security are best 
understood as "hubs" around which perspectives vie to contribute to policy. Consequently, this approach questions the notion that food security perspectives in Cameroon and elsewhere can be grouped together across all aspects of food security. While some such as Yengoh et al. have previously attempted to differentiate universal orientations toward food security in the Cameroonian context, this article suggests that categories cannot be applied with broad-brush strokes in this country or in other African places [7].

While perspective matters, viewpoints and opinions do not exist in a power vacuum. The principal perspectives that inform contests over the policies necessary to enhance each of availability, accessibility and adequacy are expressed by individuals and organizations that command varying degrees of power. On availability, for example, guided mixed economy views favouring state intervention have dominated food security policy debates. These powerful state-backed perspectives have encouraged government investments aiming to enhance food production on scales that supporters of food sovereignty and of social and ecological transformation have unsuccessfully opposed. Prominent individuals and organizations in the latter camps have in several notable cases faced repressive measures, including harassment and legal sanction, for daring to challenge paternalistic or dirigiste viewpoints. The opposition of market fundamentalists and supporters of food sovereignty to government-driven initiatives to mitigate accessibility challenges stemming from the global food crisis have similarly come up against a wall of engrained government support. On the other hand, with respect to adequacy, language reflecting international and civil society concern for greater attention to smallholders has made its way into national food security policy documents. Given that the exercise of power and efforts to countervail it are ongoing in this issue area, Cameroon's policy-makers face much more than the significant challenge of making the country's food security policy more inclusive of contrasting and divergent opinion. They also confront entrenched interests whose actions to date have impeded the development of a genuinely participatory food security policy.

Consideration of the power exercised by particular stakeholders over the language of food security policy, and over the interventions actually pursued to advance food security, is worthy of further study. So too are the identifiable efforts of practitioners to challenge the exercise of discursive or relational power by the government. Transformist and sovereigntist voices in civil society and in multilateral organizations, for example, have sought to countervail or counteract what they perceive to be the government's relative lack of attention to challenges linked to adequacy. Similarly worthy of future study is the related topic of how powerful actors have been able to keep availability and accessibility issues at the top of the policy agenda given Cameroon's nutrition transition and the reality that the access many Cameroonians enjoy to nutritious forest products is declining [51].

Attention to the divergent perspectives that populate the food security policy area ultimately enriches analyses of the contributions emerging powers are or are not making to food security through land acquisition [72,79-83]. Through focusing on three dimensions of food security across three consequential types of emerging power engagement in one country, a much more nuanced picture of perspectives on the topic emerges than is evident in the recent global literature that emphasizes land issues. Laudatory, cautionary and critical perspectives are surely as evident at the country level as they have been globally [84]. However, when attention is paid to perspectives on the ways that three significant types of emerging power engagements can impact different dimensions of food security, a much more subtle and comprehensive picture emerges. This emphasis draws attention to diversity 
between and within emerging powers across a range of interventions and discourages universal claims about "their" food security footprint. As such, it builds upon the conclusion of Jin Sato et al. that there is significant diversity in the approaches and values exuded by these powers in the area of development assistance [54].

These findings also complement and build upon ongoing work on the implications of the scaled up interventions of emerging powers for "policy space" in Cameroon and in Africa more broadly (see $[85,86]$ ). Policy space in this literature denotes the degrees of freedom that governments have to choose courses of action that are autonomous from the machinations of their powerful external partners. Given the above analysis, African policy-makers could have considerable room for manoeuvre in this area. They could, for example, employ divergent food security perspectives strategically to push back against any policy or non-policy conditionalities emerging powers seek to attach to the provision of finance. While the imposition of explicit or implicit conditions on loans has the potential to shape the food security footprint of projects linked to these disbursements, so too do the perspectives that vie to assess the potential food security footprint of these interventions. As such, policy-makers that bring a range of perspectives on the potential multidimensional food security footprint of emerging power finance to the negotiating table could be well-served. Through drawing upon a wide range of food security opinion they could potentially cut deals that foster enhanced food security outcomes. Similarly, concessions host countries make to secure direct investments from emerging powers in agriculture are not the only potential constraint on the space that African governments have to maximize the contribution of such investments to food security. Inattention to contending local perspectives on these investments can also constrain the food security effectiveness of ensuing policy measures. Consequently, this study suggests that perspective warrants explicit policy recognition. At present Cameroon's food security policies do not officially or even tacitly recognize the persistence of divides on the requisites for food security in the country. Efforts to ensure that future policies include language on this reality, and on the implications of these divides for the assessment of emerging powers vis-à-vis food are warranted. Official acknowledgement of this status quo could contribute to making policy more workable, and possibly facilitate the production of more inclusive or even effective policies.

In light of this study, vigilance and honesty with respect to bias are the order of the day. Food security is ultimately political, and the new consensus that there is no consensus with respect to the technologies and practices necessary to ensure a more sustainable food secure future is not to be taken lightly. The cultural implications of the potential growth of Africa's external dependencies as the new scramble for Africa proceeds are considerable [87]. With emerging markets projecting more power over food and foodways in Africa, high-level efforts to reflect and act upon perspectives could lead to the development of policies that make more robust contributions to durably enhancing the availability, accessibility and adequacy of food. It is hoped that those who seek greener food futures for Cameroon and for Africa more generally can draw upon this presentation to better understand the politics of the emerging power footprint, and the political context that enables and constrains the realization of more sustainable African food systems. 


\section{Acknowledgements}

A research grant from the Centre for International Governance Innovation's Africa Initiative funded this research. The author wishes to thank the many individuals that were interviewed for this study in June, July and December 2012. Due to the political sensitivity of the topic many interviewees wished to remain anonymous. I thank these individuals for their time, for the wonderful conversations, and for the documents that they were able to share with me. I have done my best in the text to honour their requests for confidence. Thanks are also owed to Florence Munoh, Ekane Ivo, and Francois Evina of the Center for International Forestry Research office in Yaoundé for the provision of exceptional logistical support and assistance each year since 2010. Mary Nana Nibba, Hubert (Nana), Olufunso Somorin, Olivier De Schutter, Evan D.G. Fraser and my wife Lauren Q. Sneyd all made significant contributions to the completion of this study.

\section{Conflicts of Interest}

The author declares no conflicts of interest.

\section{References and Notes}

1. Chang, H.-J. Rethinking Public Policy in Agriculture: Lessons from History, Distant and Recent. J. Peas. Stud. 2009, 36, 477-515.

2. Clapp, J. The Global Food Crisis and International Agricultural Policy: Which Way Forward? Global Gov. 2009, 15, 299-312.

3. Devereux, S.; Maxwell, S. Food Security in Sub-Saharan Africa; ITDG: London, UK, 2001.

4. Maxwell, S. Food Security: A Post-Modern Perspective. Food Pol. 1996, 21, 155-170.

5. Pinstrup-Andersen, P. Food Security: Definition and Measurement. Food Sec. 2009, 1, 5-7.

6. Tomlinson, I. Doubling Food Production to Feed the 9 Billion: A Critical Perspective on a Key Discourse of Food Security in the UK. J. Rur. Stud. 2013, 29, 81-90.

7. Yengoh, G.T.; Armah, F.T.; Onumah, E.E. Paths to Attaining Food Security: The Case of Cameroon. Challenges 2010, 1, 5-26.

8. Sneyd, A. Governing African Cotton and Timber Through CSR: Competition, Legitimacy and Power. Can. J. Dev. Stud. 2012, 33, 143-163.

9. De Schutter, O. Report of the Special Rapporteur on the Right to Food: Mission to Cameroon, A/HRC/22/50/Add.2. UN Human Rights Council: Geneva, Switzerland, 2012.

10. Jerven, M. Poor Numbers: How We are Misled by African Development Statistics and What to Do about It; Cornell University Press: Ithaca, NY, USA, 2013.

11. De Schutter, O. Report Submitted by the Special Rapporteur on the Right to Food, A/HRC/16/49. UN Human Rights Council, Sixteenth Session, Geneva, Switzerland, 17 December 2010.

12. FAO. Voluntary Guidelines to Support the Progressive Realization of the Right to Adequate Food in the Context of National Food Security; Food and Agriculture Organization: Rome, Italy, 2004.

13. De Schutter, O. Cameroon: Stricter Taxes for Companies Drawing on Natural Resources to Better Tackle Hunger. Report of the UN Special Rapporteur on the Right to Food, Yaoundé, Cameroon /Geneva, Switzerland, 23 July 2012. 
14. Citizens Association for the Defense of Collective Interests (ACDIC). Food Sovereignty Campaign: Let's Help Them Feed Us! ACDIC: Yaoundé, Cameroon, 2006.

15. République du Cameroun. Rapport de Mise en Oeuvre de la Stratégie du Développement du Secteur Rural; MINEPAT: Yaoundé, Cameroon, 2012. (In French)

16. WFP and FAO. Cameroon: Comprehensive Food Security and Vulnerability Analysis; WFP and FAO: Yaoundé, Cameroon, 2011.

17. FAO. Foreign Agricultural Investment Country Profile: Cameroon; FAO: Rome, Italy, 2012.

18. IMF. Poverty Reduction Strategy Paper: Cameroon; IMF: Washington, DC, USA, 2010.

19. PAM. Situation de la Sécurité Alimentaire et des Marchés au Cameroun; PAM and FAO: Yaoundé, Cameroon, 2011. (In French)

20. Bates, R. Markets and States in Tropical Africa: The Political Economy of Agricultural Policies, 2nd ed.; University of California Press: Berkeley, CA, USA, 2005.

21. World Bank. Accelerated Development in Sub-Saharan Africa; World Bank: Washington, DC, USA, 1981.

22. Godfray, H.C.J.; Beddington, J.R.; Crute, I.R.; Haddad, L.; Lawrence, D.; Muir, J.F.; Pretty, J.; Robinson, S.; Thomas, S.M.; Toulmin, C. Food Security: The Challenge of Feeding 9 Billion People. Science 2010, 12, 327.

23. Lee, D.R.; Headey, D.; Wiebe, K.; Ndulo, M. Lessons of the Food and Financial Crises: Renewing Sub-Saharan Africa's Commitment to Food Security and Economic Growth. In The Food and Financial Crises in Sub-Saharan Africa: Origins, Impacts and Policy Implications; Lee, D.R., Ndulu, M.B., Eds; CABI: Oxford, UK, 2011.

24. Nabarro, D. UN System High Level Task Force on Global Food Security Offers its Comprehensive Approach for Food Security and Nutrition for UNCTAD XIII. Available online: http://unctadxiii.org/en/Documents/UN\%20System\%20High\%20Level\%20TaskForceonGlobalFo odSecurityforUNCTAD\%20XIII.pdf (accessed on 26 March 2014)

25. World Bank. World Development Report 2008: Agriculture for Development; World Bank: Washington, DC, USA, 2007.

26. Republic of Cameroon. Cameroon Vision 2035: Working Paper; Ministry of the Economy, Planning and Regional Development: Yaoundé, Cameroon, 2009.

27. Republic of Cameroon. Summary of the National Programme for Food Security; Prime Minister's Office: Yaoundé, Cameroon, 2009.

28. Ngniado, B. Etude sur Les Importations Alimentaires au Cameroun; Bureau Sous-Régional de la FAO pour l'Afrique Centrale: Libreville, Gabon, 2011. (In French)

29. Cooksey, B. Marketing Reform? The Rise and Fall of Agricultural Liberalisation in Tanzania. Dev. Pol. Rev. 2011, 29, S57-S81.

30. Stocking, B. Small Farmers Can Land a Knockout Blow Against Poverty. Financial Times (US Edition), 1 October 2012, p. 11.

31. UNDP. Africa Human Development Report 2012: Towards a Food Secure Future; UNDP: New York, NY, USA, 2012.

32. Altieri, M. Agroecology: The Science of Sustainable Agriculture; Westview Press.: Boulder, CO, USA, 1995. 
33. IAASTD. Executive Summary of the Synthesis Report of the International Assessment of Agricultural Knowledge, Science and Technology for Development; IAASTD: Johannesburg, South Africa, 2008.

34. Pretty, J.N.; Noble, A.D.; Bossio, D.; Dixon, J.; Hine, R.E.; Penning de Vries, F.W.T.; Morison, J.I.L. Resource-conserving Agriculture Increases Yields in Developing Countries. Environ. Sci. Technol. 2006, 40, 1114-1119.

35. UNCTAD-UNEP. Organic Agriculture and Food Security in Africa; UN: New York, NY, USA and Geneva, Switzerland, 2008.

36. Medou, J.C. Présentation Sommaire du Secteur Rural au Cameroun, Comité de Pilotage du Développement Rural-MINEPAT, Yaoundé, Cameroun, 7 February 2012. (In French)

37. République du Cameroun. Agri-Stat Cameroun: Annuaire des Statistiques du Secteur Agricole Campagnes 2007 \& 2008; MINADER: Yaoundé, Cameroun, 2010. (In French)

38. NU ECOSOC. Observations Finales du Comité des Droits Économiques, Sociaux et Culturels: Cameroun; Nations Unis ECOSOC: Genève, Switzerland, 2011. (In French)

39. Wittman, H.; Desmarais, A.; Wiebe, N. The Origins \& Potential of Food Sovereignty. In Food Sovereignty: Reconnecting Food, Nature and Community; Desmarais, A.A., Wiebe, N., Wittman, H., Eds.; Fernwood: Halifax, NS, Canada, 2010; pp. 1-14.

40. Coalition. Zéro Produit Alimentaire Importé au Comice; Campagne Zéro Produit Alimentaire Importé au Comice: Ebolowa, Cameroun, 2010. (In French)

41. Coalition. Cérémonie Dégustation des Produits Camerounais; Campagne Zéro Produit Alimentaire Importé au Comice: Yaoundé, Cameroun, 2010. (In French)

42. Kpodor, E. Les Importations Alimentaires; les Déficits de Production, les Contraintes de Production; et Les Solutions Gouvernementales; Représentant resident du FMI: Yaoundé, Cameroun, 2012. (In French)

43. Citizens Association for the Defense of Collective Interests (ACDIC). Frozen Chicken is Dangerous! ACDIC: Yaoundé, Cameroon, 2004.

44. Cameroun: Maîtrise des Prix et Protection du Consommateur-Les Pouvoirs Public Prennent Les Devants (Publicité). Jeune Afrique, 8-14 July 2012, pp. 17-20. (In French)

45. Medou, J.C. Analyse de la Flambée des Prix des Produits Alimentaires au Cameroun; FAO: Yaoundé, Cameroun, 2008. (In French)

46. IMF. Staff Report for the 2011 Article IV Consultation: Cameroon; IMF: Washington, DC, USA, 2011.

47. Djarmaila, G. La Mirap Redonne le Sourire. Cameroun Tribune, 10 July 2012, p. 13. (In French)

48. Van de Walle, N. Rice Politics in Cameroon: State Commitment, Capability and Urban Bias. J. Mod. Af. Stud. 1989, 27, 579-599.

49. Sneyd, A. Cameroon: Let them Eat Local Rice. Available online: http://www.africaportal.org/ articles/2012/08/27/cameroon-let-them-eat-local-rice (accessed on 26 March 2014).

50. Konings, P. Crisis and Neoliberal Reforms in Africa: Civil Society and Agro-Industry in Anglophone Cameroon's Plantation Economy; Langaa and African Studies Centre: Bamenda, Cameroon and Leiden, The Netherlands, 2011.

51. Sneyd, L. Wild Food, Prices, Diets and Development: Sustainability and Food Security in Urban Cameroon. Sustainability 2013, 5, 4728-4759. 
52. Njonga, B. ACDIC, Yaoundé, Cameroun. Personal communication, 27 June 2012.

53. République du Cameroun. Strategie Nationale de Developpement de la Riziculture au Cameroun; MINADER: Yaoundé, Cameroun, 2009. (In French)

54. Sato, J.; Shiga, H.; Kobayashi, T.; Kondoh, H. "Emerging Donors" from a Recipient Perspective: An Institutional Analysis of Foreign Aid in Cambodia. World Dev. 2011, 39, 2091-2104.

55. République du Cameroun. Tableau Synoptique des Lots de Terres; MINADER: Yaoundé, Cameroun, 2012. (In French)

56. Konings, P. China and Africa in the Era of Neoliberal Globalisation with Cameroon as a Case Study. In The Politics of Neoliberal Reforms in Africa: State and Civil Society in Cameroon; Langaa and African Studies Centre: Bamenda, Cameroon and Leiden, The Netherlands, 2011; pp. 177-203.

57. Cameroon: The Window of Africa (Advertisement). Financial Times (US Edition), 15 July 2011, p. 5.

58. UN Economic Commission for Africa (ECA). Report Blames Multinationals For Illicitly Transferring most of the \$1.5 Trillion Made in Africa Each Year. UN ECA Press Release 129/2012, Addis Ababa, Ethiopia, 27 July 2012.

59. Jolly, R.; Emmerij, L.; Ghai, D.; Lapeyre, F. UN Contributions to Development Thinking and Practice; Indiana University Press: Bloomington and Indianapolis, IN, USA, 2004.

60. International Crisis Group. Cameroon: Fragile State? Crisis Group Africa Report No. 160; Crisis Group: Dakar, Senegal; Nairobi, Kenya; Brussels, Belgium, 2010.

61. FAO. Voluntary Guidelines on the Responsible Governance of Tenure of Land, Fisheries and Forests in the Context of National Food Security; FAO: Rome, Italy, 2012.

62. Hoyle, D.; Levang, P. Oil Palm Development in Cameroon; WWF \& IRD/CIFOR: Yaoundé, Cameroon, 2012.

63. Nguiffo, S.; Schwartz, B. Herakles' 13th Labour? A Study of SGSOC's Land Concession in South-West Cameroon; CED \& Relufa: Yaoundé, Cameroon, 2012

64. Oakland Institute. Massive Deforestation Portrayed as Sustainable Development: The Deceit of Herakles Farms in Cameroon; Oakland Institute Land Deal Brief: Oakland, CA, USA, 2012.

65. Ngalame, E.N. Cameroon's Forests Pressured as Leaders Welcome Palm Oil Investors. Available online: http://www.trust.org/item/?map=cameroons-forests-pressured-as-government-welcomespalm-oil-investors/ (accessed on 26 March 2014).

66. Khan, S.A.; Baye, F.M.; Tange, G.K. The Impact of China-Africa Trade Relations: The Case of Cameroon. Available online: http://dspace.cigilibrary.org/jspui/bitstream/123456789/32376/1/ CameroonTradeimpact.pdf?1 (accessed on 26 March 2014).

67. Cameroon's Commitment to the Green Economy (Advertisement). Financial Times Special Report: Africa and the Green Economy 2012, 20 June 2012, pp. 4-5.

68. Schwartz, B.; Hoyle, D.; Nguiffo, S. Emerging Trends in Land-Use Conflicts in Cameroon; WWF, CED and RELUFA: Yaoundé, Cameroon, 2012.

69. De Schutter, O. UN Special Rapporteur on the Right to Food, Geneva, Switzerland. Personal communications at Kribi and Edea, Cameroon, 21 July 2012.

70. Levitt, T. Palm Oil Giants Target Africa in "Land Grab" Following Indonesia Deforestation Ban. Available online: http://www.theecologist.org/News/news_analysis/823928/palm_oil_giants_target_ africa_in_land_grab_following_indonesia_deforestation_ban.html (accessed on 26 March 2014). 
71. Herakles Farms Announces Update on its Cameroon Palm Oil Subsidiary SGSOC. Available online: http://www.prnewswire.com/news-releases/herakles-farms-announces-update-on-its-cameroonpalm-oil-subsidiary-sgsoc-158594925.html (accessed on 26 March 2014).

72. Edoho, F.M. Globalization and Marginalization of Africa: Contextualization of China-Africa Relations. Africa Today 2011, 58, 102-124.

73. McMichael, P. The Land Grab and Corporate Food Regime Restructuring. J. Peas. Stud. 2012, 39, 681-701.

74. Putzel, L.; Assembe-Mvondo, S.; Ndong, L.B.B.; Banioguila, R.P.; Cerutti, P.O.; Chupezi Tieguhong, J.; Djeukam, R.; Kabuyaya, N.; Lescuyer, G.; Mala, W. Chinese Trade and Investment and the Forests of the Congo Basin; CIFOR Working Paper 67; CIFOR: Bogor, Indonesia, 2011.

75. Timmer, C.P. Reflections on Food Crises Past. Food Pol. 2010, 35, 1-11.

76. De Schutter, O. Interim Report of the Special Rapporteur on the Right to Food, A/66/262. UN General Assembly, Sixty-Sixth Session, New York, NY, USA, 4 August 2011.

77. Gauthier, B.; Zeufack, A. Governance and Oil Revenues in Cameroon. In Plundered Nations? Successes and Failures in Natural Resource Extraction; Collier, P., Venables, A.J., Eds.; Palgrave Macmillan: Basingstoke, UK, 2011.

78. Nyuylime, L.P. Valorising Local Processing. Alter Eco 2012, 42, 10-23.

79. Cotula, L.; Vermeulen, S. Deal or No Deal: The Outlook for Agricultural Land Investment in Africa. Int. Aff. 2009, 85, 1233-1247.

80. Hallam, D. International Investment in Developing Country Agriculture-Issues and Challenges. Food Sec. 2011, 3, S91-S98.

81. Toulmin, C.; Bindraba, P.; Borras, S.; Mwangi, E.; Saue, S. Land Tenure and International Investments in Agriculture: A Report by High Level Panel of Experts on Food Security and Nutrition; FAO: Rome, Italy, 2011.

82. Manning, R. Will "Emerging Donors" Change the Face of International Cooperation? Overseas Development Institute: London, UK, 2006.

83. Robertson, B.; Pinstrup-Anderson, P. Global Land Acquisition: Neo-Colonialism or Development Opportunity? Food Sec. 2010, 2, 271-283.

84. Africa Progress Panel. Africa Progress Report 2012-Jobs, Justice and Equity: Seizing Opportunities in Times of Global Change; APP: Lausanne, Switzerland, 2012.

85. Akyüz, Y. Multilateral Disciplines and the Question of Policy Space; Third World Network Trade and Development Series 38; Third World Network: Penang, Malaysia, 2009.

86. Poon, D. South-South Impacts on African Development Policy Spaces; NSI: Ottawa, ON, Canada, 2013.

87. Blouin, C.; Hawkes, C.; Henson, S.; Drager, N.; Dubé, L. Trade, Health and Dietary Change. In Trade, Food, Diet and Health: Perspectives and Policy Options; Hawkes, C., Blouin, C., Henson, S., Drager, N., Dubé, L., Eds.; Wiley-Blackwell: Oxford, UK, 2010.

(C) 2014 by the author; licensee MDPI, Basel, Switzerland. This article is an open access article distributed under the terms and conditions of the Creative Commons Attribution license (http://creativecommons.org/licenses/by/3.0/). 